\title{
SYNTHESIS OF 1-METHYL-2-HYDROXYIMINOMETHYL-ARYL-PYRIDINIUM SALTS WITH POTENTIAL AS ACETYL-CHOLINESTERASE REACTIVATORS
}

\author{
Ivone Carvalho ${ }^{\text {a,b }}$ and Joseph Miller ${ }^{\text {a,c }}{ }^{*}$ \\ ${ }^{a}$ Universidade de Sāo Paulo, Faculdade de Cienncias Farmacêuticas, Cidade Universitária, \\ 05508-900, São Paulo-SP., Brasil. \\ ${ }^{b}$ Universidade de Säo Paulo, Faculdade de Ciências Farmacêuticas de Ribeirāo Preto, \\ Campus Universitário, Monte Alegre, 14040-903, RibeirāoPreto-SP., Brasil. \\ ${ }^{c}$ Universidade Federal da Paraíba, Laboratório de Tecnologia Farmacêutica e Departamento \\ de Quimíca, Campus I, Caixa Postal 5009, 58051-970, Joăo Pessoa, PB., Brasil.
}

\begin{abstract}
A series of 1-methyl-2-hydroxyiminomethyl-aryl-pyridinium salts has been prepared, as new potential antidotes of poisoning by organo-phosphorus compounds. Several synthetic sequences were tested and all but one, with an internal branch, rejected because they were judged inconvenient and/or because of low yields. 2-Picoline was oxidized to picolinic acid and this converted to 2-(4-X-benzoyl)pyridines either via decarboxylation followed by nucleophilic addition to selected aromatic aldehydes and oxidation of the secondary alcohols thus obtained or by conversion to picolinoyl chloride followed by Friedel-Crafts reactions with selected mono-substituted arenes. The 2-aroylpyridines were then converted to the corresponding oximes ( $E$ and $Z$ forms in some cases), followed by methylation of pyridine nitrogen.
\end{abstract}

\section{Introduction}

Organo-phosphorus insecticides are widely used. They, with nerve gases, are highly toxic anticholinesterase agents (inhibitors of acetyl-cholinesterase), acting primarily through the nervous system. It is clearly important that acetyl-cholinesterase reactivators should be available as antidotes of poisoning by such compounds. One of the most widely used is Pralidoxime (2-PAM) or 1-methyl-2-hydroxyiminomethyl-pyridinium chloride (1). The key action of these acetyl-cholinesterase reactivators is believed to stem from the nucleophilic attack by their hydroxy-imino oxygen on phosphorus in the inhibited enzyme eliminating the inhibitor in a complex with the reactivator, liberating the enzyme and exposing its esterase site. Despite its efficacy, 2-PAM being highly polar and water-soluble is rapidly eliminated from the organism. Thus its action is essentially restricted to the peripheral nervous system.

Other compounds are used and many of these are also 1-methyl-2hydroxyiminomethyl-pyridinium salts. Some are more active but have undesirable characteristics such as pain on application, instability in aqueous media and higher incidence of adverse effects $(2,3)$.

We were thus led to initiate a study of related compounds which might offer pharmacological and toxicological advantage over 2-PAM and other compunds used in treatment of organo-phosphorus poisoning. 
Our aim has been to develop convenient syntheses of a group of 1 methyl-2-hydroxyiminomethyl-pyridinium salts of greater lipophilicity than 2-PAM, maintaining the essential molecular geometry, together with the nucleophilicity of the hydroxyimino oxygen. For this purpose we selected a group of 1-methyl-2-hydroxyiminomethyl- aryl-pyridinium iodides, some of which we obtained in both $\mathrm{Z}$ and $\mathrm{E}$ forms. Their skeletal structure is :<smiles>[X]c1ccc(C(O)c2cccc[n+]2C)cc1</smiles>

The efficacy of these compounds as acetyl-cholinesterase reactivators is the subject of a parallel study.

\section{Results and Discussion}

Various synthetic sequences were tested and all but one rejected because of low yields and/or because they were judged to be substantially less convenient.

1.

The reaction sequence chosen, which has an internal branch, is outlined in Scheme

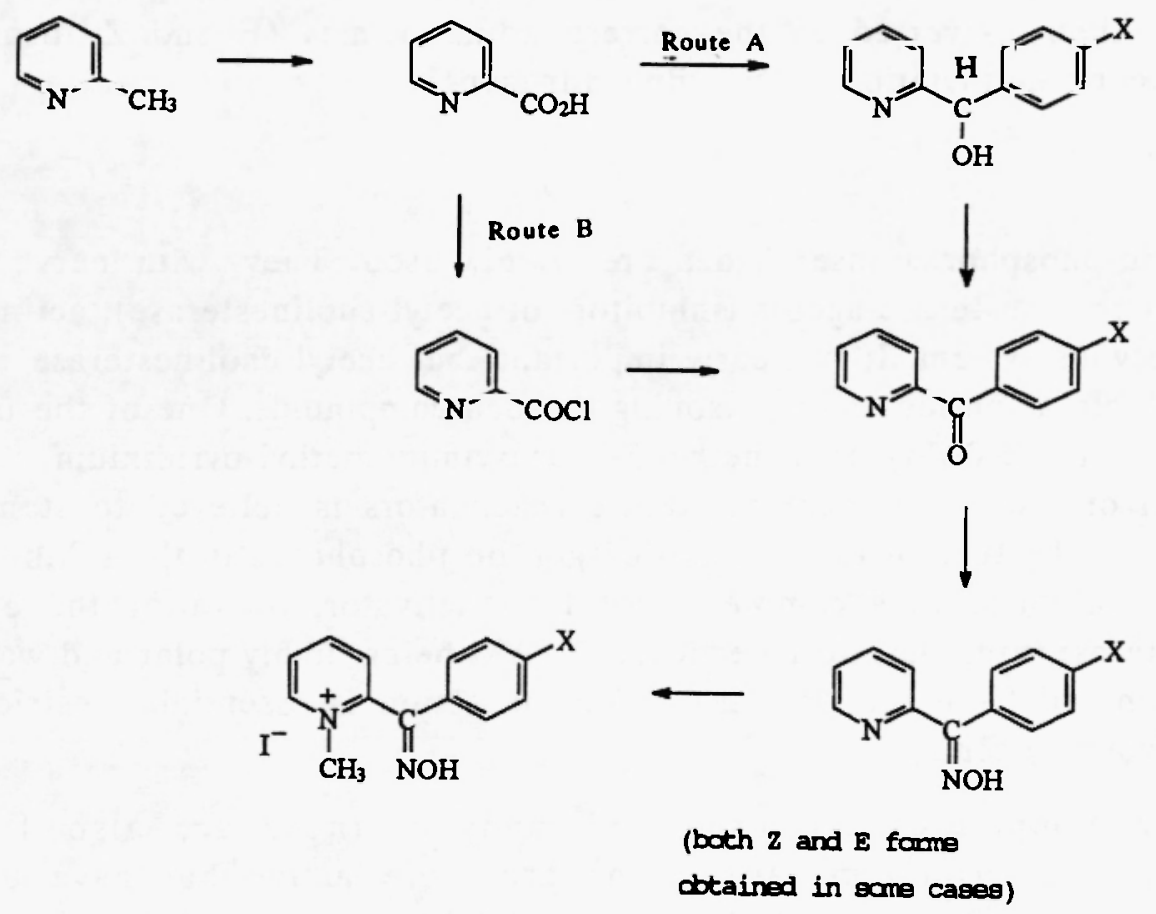

Scheme 1 : Reaction sequence for synthesis of 1-methyl-2-hydroxyiminomethyl-aryl- pyridinium salts 
The sequence, incorporating route $A$ was used to obtain the product with $\mathrm{X}=\mathrm{Cl}$, $\mathrm{F}, \mathrm{NO}_{2}, \mathrm{OCH}_{3}$; while the sequence, incorporating route $\mathrm{B}$ was used to obtain the products with $\mathrm{X}=\mathrm{H}, \mathrm{CH}_{3}$.

The initial step, oxidation of 2-picoline to picolinic acid was carried out according to the literature (4), but with a modification to improve the isolation of the acid, which is highly soluble in water. We isolated it conveniently by continuous extraction with benzene in a Soxhlet appratus.

Route A :

This route was preferred for $\mathrm{X}=\mathrm{Cl}, \mathrm{F}, \mathrm{NO}_{2}, \mathrm{OCH}_{3}$, despite relatively low yields of only ca $40 \%$ because it is so easily and rapidly carried out, without a catalyst, giving pure products.

It involves simply heating picolinic acid with the appropriate aromatic aldehyde in refluxing mesitylene (b.p. $165^{\circ} \mathrm{C}$ ) (5). The reaction is considered to occur via decarboxylation, furnishing an anionic centre at the 2-position. This, acting as a nucleophile, adds to the carbonyl carbon atom (as shown):
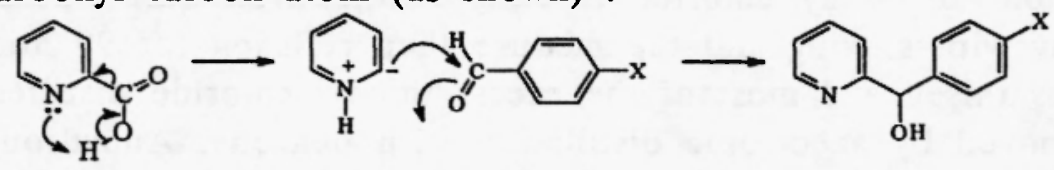

The oxidation of the carbinol to the desired ketone was carried out conveniently and in good yield using chromic acid in acetone $(6,7)$. This step was unnecessary in the case of $\mathrm{X}=\mathrm{NO}_{2}$ because the carbinol function was oxidized in situ by the $\mathrm{NO}_{2}$ group of the reagent. The yield was less $(28 \%)$ as expected, but as a one-pot sequence was quite acceptable.

\section{Route B}

This route was preferred for $\mathrm{X}=\mathrm{H}, \mathrm{CH}_{3}$. The indications of Villani et al. (8) were followed, though we studied various minor modifications for the preparation of picolinoyl chloride which then was reacted with benzene or toluene in a Friedel-Crafts reaction. The best yields (53\% for 2-benzoyl-pyridine and $68 \%$ for p-toluoyl-pyridine) were obtained when most of the excess thionyl chloride, used in the first step, was removed by fractional distillation and the rest removed by azeotropic distillation with benzene and then with toluene.

There were also difficulties in extracting the ketones at the end of the reactions. The best method was by extraction with warm chloroform.

The ketones, obtained by route $\mathrm{A}$ or $\mathrm{B}$, were converted into oximes following the indication of Huntress and Walter (9) or of Case and McMenamin (10), depending on the yields obtained in each method.

The stereo-isomer $\mathrm{Z}$ of the oximes has the $\mathrm{OH}$ group directed towards the benzene ring so that the pyridine nitrogen is free to co-ordinate to metals. It is also able to interact with the hydrogen of chloroform.

The stereo-isomer $\mathrm{E}$ of the oximes has the $\mathrm{OH}$ group directed towards the pyridine ring with hydrogen-bonding to the annular nitrogen. 
These points led us to select the following two methods for separation of the $E$ and $Z$ stereo-isomers. The first method takes advantage of the differential solubility in chloroform obtaining the less soluble $E$ stereo-isomer. The filtrate is treated with $\mathrm{Cu}(\mathrm{II}) \mathrm{SO}_{4}$ (aqueous acid): the $\mathrm{Z}$ stereo-isomer precipitates as a complex. After passage of $\mathrm{H}_{2} \mathrm{~S}(\mathrm{~g})$ and filtration the $\mathrm{Z}$ stereo-isomer is recovered by basification and filtration.

The second method involves initial treatment with $\mathrm{Cu}(\mathrm{II}) \mathrm{SO}_{4}$ (aqueous acid) precipitating the $\mathrm{Z}$ stereo-isomer as a complex. Following passage of $\mathrm{H}_{2} \mathrm{~S}(\mathrm{~g}$ ) and filtration the A stereo-isomer is recovered from the complex. The $E$ isomer was obtained by neutralization of the initial filtrate. The final stage of quaternization of the pyridine nitrogen was carried out conventionally using methyl iodide at ambient temperature $(11,12)$.

\section{Experimental Section}

2-Benzoyl-pyridine $1: 0.5$ Mole of previously dried picolinic acid was placed in a three-necked flask, fitted with a reflux condenser, a mechanical stirrer and a dropping funnel. Excess ( 0.5 mole) of thionyl chloride, recently distilled from quinoline and linseed oil, was added slowly with stirring and the mixture then refluxed for 90 minutes. The bath temperature was raised and most of the excess thionyl chloride distilled off. The last traces were removed by azeotropic distillation with benzene. Anhydrous benzene (0.247 mole) was added to the reaction mixture. It was cooled in an ice-bath and 0.185 mole of anhydrous aluminium chloride was added in small portions over 30 minutes. It was refluxed for 6 hours with vigorous stirring. After cooling it was added to a mixture of ice and conc. hydrochloric acid, With stirring. The warm chloroform extract was washed with water and dried over anhydrous sodium sulfate. After removal of solvent the product was vacuum-distilled at $130-135{ }^{\circ} \mathrm{C}$ and 3 torr. 2- Benzoyl-pyridine was obtained in 53 $\%$ yield; lit. (8) $87 \%$ yield; b.p. $130-133{ }^{\circ} \mathrm{C}, 1-2$ torr; NMR $\left(\mathrm{CDCl}_{3}\right): \delta=8.5-8.8$ (d, $1 \mathrm{H}), 7.7-8.3(\mathrm{~m}, 3 \mathrm{H}), 7.3-7.7(\mathrm{~m}, 5 \mathrm{H})$. lit. (13) : 8.5-8.7 (d, 1H), 7.6 - 8.2 (m, 3H), 7.2-7.6 (m, 5H), IR ( NaCl film) : $\nu_{\max }\left(\mathrm{cm}^{-1}\right)=3150-3050(\mathrm{Ar}-\mathrm{H}$ and Py-H); 1660 $(\mathrm{C}=\mathrm{O})$; lit. (14): 3200-3000 (Ar-H and Py-H), $1660(\mathrm{C}=\mathrm{O})$.

2-p-Toiuoyl-pyridine 2 : This was obtained analogously to preparation 1. Azeotropic distillation with toluene was used to remove the last traces of thionyl chloride before 0.247 mole of toluene was added to the reaction mixture. It was then heated at $75{ }^{\circ} \mathrm{C}$ for $4.30 \mathrm{hrs}$. Following solvent removal in the final stages, the product was distilled between $120-140{ }^{\circ} \mathrm{C}$ at 4 torr. 2-p-Toluoyl-pyridine was obtained in $68 \%$ yield; NMR $\left(\mathrm{CDCl}_{3}\right): \delta=8.5-8.8(\mathrm{~d}, 1 \mathrm{H}), 7.6-8.2(\mathrm{~m}, 3 \mathrm{H}), 7.0-7.6(\mathrm{~m}, 4 \mathrm{H}), 2.3(\mathrm{~s}, 3 \mathrm{H}) ; \operatorname{IR}(\mathrm{NaCl}$ film) : $v_{\max }\left(\mathrm{cm}^{-1}\right)=3100-3000(\mathrm{Ar}-\mathrm{H}$ and $\mathrm{Py}-\mathrm{H}), 2950\left(\mathrm{CH}_{3}\right), 1660(\mathrm{C}=\mathrm{O})$.

p-Methoxyphenyl-2-pyridinyl-methanol $3: 0.0285$ Mole of dried picolinic acid, 0.176 mole of p-anisaldehyde and $24.9 \mathrm{ml}$ of mesitylene were placed in a two-necked flask fitted with a reflux condenser and a gas exit tube. The mixture was refluxed until the evolution of $\mathrm{CO}_{2}$ ceased. After cooling, the reaction mixture was extracted with $3 \mathrm{~N} \mathrm{HCl}$ and this was neutralized with aq. $\mathrm{NaOH}$. The precipitate thus obtained was filtered off, washed with water and dried at ambient temperature. p-Methoxyphenyl-2-pyridinyl-methanol was obtained in $38 \%$ yield; m.p. $133-133{ }^{\circ} \mathrm{C}$; $\mathrm{NMR}\left(\mathrm{CDCl}_{3}\right): \delta=8.5-8.9$ (d, $\left.1 \mathrm{H}\right), 6.7-8.0$ 
(m, 7H), 5.7 (s, 1H-carbinol), $3.8(\mathrm{~s}, 3 \mathrm{H})$; IR (KBr pellet) : $\nu_{\max }\left(\mathrm{cm}^{-1}\right)=3400-3000$ (combined O-H; Ar-H; Py-H), 2850 (C-H, O- $\mathrm{CH}_{3}$ and carbinol), 1250 (Ar-OR), 1025 (C-O).

2-p-Nitrobenzoyl-pyridine 4 : The procedure used in preparation 3 was followed. However, in this case, the carbinol formed was oxidized in situ by the nitro-group.

The quantities used were 0.0285 mole of picolinic acid, 0.114 mole of p-nitro-benzaldehyde and $24.0 \mathrm{ml}$ of mesitylene. 2-p-Nitrobenzoyl-pyridine was obtained in $28 \%$ yield. It had m.p. 95- $98{ }^{\circ} \mathrm{C}$; NMR (DMSO-d 6$): \delta=8.6-8.9(\mathrm{~d}, 1 \mathrm{H}), 8.3(\mathrm{~s}$, 4H), 7.4-8.3 (m, 3H); IR (KBr pellet) : $\nu_{\max }\left(\mathrm{cm}^{-1}\right)=3080-3020(\mathrm{Ar}-\mathrm{H}$ and Py-H), 1670 $(\mathrm{C}=\mathrm{O}), 1510$ and $1350\left(\mathrm{C}-\mathrm{NO}_{2}\right)$.

P-Fluorophenyl-2-pyridinyl-methanol 5 : The procedure used in preparation $\mathbf{3}$ was generally followed, using 0.0285 mole of picolinic acid, 0.114 mole of p-fluorobenzaldehyde and $15.0 \mathrm{ml}$ of mesitylene. The viscous oil obtained was extracted with chloroform and dried over anhydrous sodium sulfate. A precipitate formed spontaneously and after filtration was recrystallized from ethanol. p-Fluorophenyl-2-pyridinyl-methanol was thus obtained in $40 \%$ yield; m.p. $99-102{ }^{\circ} \mathrm{C}$; NMR $\left(\mathrm{CDCl}_{3}\right): \delta=8.3-8.6(\mathrm{~d}, 1 \mathrm{H}) ; 6.7-8.2(\mathrm{~m}, 7 \mathrm{H})$; 5.6-6.0 (dd, 2H-carbinol); IR (KBr pellet): $\nu_{\max }\left(\mathrm{cm}^{-1}\right)=3300-3000(\mathrm{O}-\mathrm{H}), 2920-2850$ (C-H, carbinol), 1210 (C-F).

P-ChIorophenyl-2-pyridinyI-methanol 6: This was obtained analogously to preparation 3 , using 0.285 mole of picolinic acid, 0.142 mole of p-chlorobenzaldehyde and $15.0 \mathrm{ml}$ of mesitylene. p-Chlorophenyl-2-pyridinyl-methanol was thus obtained in $35 \%$ yield; m.p. 81-83 ${ }^{\circ} \mathrm{C}$; NMR $\left(\mathrm{CDCl}_{3}\right): \delta=8.3-8.5(\mathrm{~d}, \mathrm{lH}), 6.9-7.9(\mathrm{~m}, 7 \mathrm{H}), 5.7$ (s, $1 \mathrm{H}$ carbinol); IR $\left(\mathrm{KBr}\right.$ pellet): $v_{\max }\left(\mathrm{cm}^{-1}\right)=3300-3000$ (combined O-H; Ar-H; Py-H), 2900-2800 (C-H-carbinol), 1050 (C-Cl).

2-p-Methoxybenzoyl-pyridine I : p-Methoxyphenyl-2-pyridinyl-methanol $(0.0218$ mole $)$ was placed in a two-necked flask fitted with a mechanical stirrer and dropping-funnel, immersed in an ice-salt freezing-mixture. A mixture of $2.0 \mathrm{~g}$ of chromium trioxide, 2.0 ml of conc. $\mathrm{H}_{2} \mathrm{SO}_{4}$ and $9.0 \mathrm{ml}$ of water was added slowly through the funnel, while stirring vigorously. The cooling-bath was removed and stirring continued for 3 hours at ambient temperature. The reaction mixture was then poured into a mixture of ice and water forming a yellow precipitate. This was filtered off and washed with cold water. 2-p-Methoxy-benzoyl-pyridine was thus obtained in $70 \%$ yield; m.p. 95-96 ${ }^{\circ} \mathrm{C}$; NMR $\left(\mathrm{CDCl}_{3}\right): \delta=8.6-8.8(\mathrm{~d}, \mathrm{lH}), 6.8-8.3(\mathrm{~m}, 7 \mathrm{H}), 3.9(\mathrm{~s}, 3 \mathrm{H}) ; \mathrm{IR}\left(\mathrm{KBr}\right.$ pellet) $: \nu_{\max }\left(\mathrm{cm}^{-1}\right)$ =3080-3000 (Ar-H and Py-H), 2950-2850 (C-H, OCH $\left.{ }_{3}\right), 1645$ (CO), 1250 (Ar-OR).

2-p-Fluorobenzoyl-pyridine 8 : The procedure of preparation $I$ was followed, using the corresponding aryl-pyridyl-methanol and in the same molar proportions. 2-p-Fluorobenzoyl-pyridine was thus obtained in $41 \%$ yield; m.p. $83-84{ }^{\circ} \mathrm{C}$; $\mathrm{NMR}\left(\mathrm{CDCl}_{3}\right)$ : $\delta=8.5-8.8(\mathrm{~d}, \mathrm{lH})$ 7.6-8.5 (m, 4H) 6.8-7.5 (m, 3H); IR (KBr pellet) $: \nu_{\max }\left(\mathrm{cm}^{-1}\right)=3060$ (Ar-H and Py-H), $1655(C=O), 1220$ (C-F).

2-p-Chiorobenzoyl-pyridine 2 : The procedure of preparation $Z$ was followed, using the corresponding aryl-pyridinyl-methanol and in the same molar proportions. 
2-p-Chlorobenzoyl-pyridine was thus obtained in $86 \%$ yield; m.p. $64-65{ }^{\circ} \mathrm{C}$; NMR $\left(\mathrm{CDCl}_{3}\right): \delta=8.4-8.8(\mathrm{~d}, 1 \mathrm{H}), 7.6-8.3(\mathrm{~m}, 4 \mathrm{H}), 7.2-7.5(\mathrm{~m}, 3 \mathrm{H})$; IR (KBr pellet) : $\nu_{\max }$ $\left(\mathrm{cm}^{-1}\right)=3080(\mathrm{Ar}-\mathrm{H}$ and $\mathrm{Py}-\mathrm{H}), 1655(\mathrm{C}=\mathrm{O}), 1080(\mathrm{C}-\mathrm{Cl})$.

2-Hydroxyiminomethyl-phenyl-pyridine 10 : The method of Huntress and Walter (9) was followed. 2-Benzoyl-pyridine $(0.01 \mathrm{~mole})$ in $3.0 \mathrm{ml}$ of ethanol was placed in a round-bottomed flask, fitted with a condenser. Hydroxylamine hydrochloride (0.026 mole) dissolved in $4.0 \mathrm{ml}$ of water was added with magnetic stirring. Then 0.045 mole of sodium hydroxide in $4.0 \mathrm{ml}$ of water was added and the mixture heated until it began to boil. After cooling, the mixture was acidified with glacial acetic acid then allowed to stand. The rose-coloured precipitate which formed was filtered off and washed with water.

The Z- and E-stereoisomeric mixture was refluxed with dry chloroform for 15 minutes. The less soluble E-stereoisomer precipitated and was filtered off and recrystallized from ethanol. The chloroformic and ethanolic filtrates were united and evaporated to dryness. The residue was dissolved in $15.0 \mathrm{ml}$ of $3 \mathrm{~N}$ aq. $\mathrm{HCl}$ and treated with $0.4 \mathrm{~g}$ of copper sulfate dissolved in water. After standing for several hours the green precipitate was filtered off and washed with water. Hydrogen sulfide was bubbled through the filtrate and copper sulfide filtered off. The filtrate was treated with aq. $\mathrm{NH}_{3}$ until it reached pH 6. A white precipitate formed, was filtered off and recrystallized from ethanol. The E-stereoisomer, obtained in $43 \%$ yield; m.p. $152-155.5{ }^{\circ} \mathrm{C}$. lit. (9) : yield $=51 \%$ m.p. 150-152.5 ${ }^{\circ} \mathrm{C}$; NMR (DMSO-d 6 ): $\delta=11.5(1 \mathrm{H}, \mathrm{OH}) ; 8.4-8.6(\mathrm{~d}, 1 \mathrm{H}), 7.4(\mathrm{~s}, 5 \mathrm{H}), 7.0-8.0$ (m, 3H); IR (KBr pellet) : $v_{\max }\left(\mathrm{cm}^{-1}\right)=3400-2600$ (combined O-H, Ar-H, Py-H), 1550 $(\mathrm{C}=\mathrm{N})$. Z-isomer : yield = $12.6 \%$; m.p. $166-166.5{ }^{\circ} \mathrm{C}$. lit. (9) : yield $11 \%$; m.p. 165-167 ${ }^{\circ} \mathrm{C}$. The NMR and IR spectra were similar to those of the E-isomer.

2-Hydroxyiminomethyl-(p-methylphenyl)-pyridine 11 : This was prepared analogously to preparation 10, substituting 2-p-toluoyl-pyridine. The E-isomer was obtained in $23 \%$ yield; m.p. $168-170{ }^{\circ} \mathrm{C}$; NMR (DMSO-d 6 ) : $\delta=8.5-8.8$ (d, $\left.1 \mathrm{H}\right), 7.0-8.2$ (m, 7H), 2.3 (s, $3 \mathrm{H}$ ); IR (KBr pellet) : $v_{\max }\left(\mathrm{cm}^{-1}\right)=3400-2700$ (combined O-H, Ar-H, Py-H), $1585(\mathrm{C}=\mathrm{N}$ ). The Z-isomer was obtained in $13 \%$ yield; m.p. $182-185{ }^{\circ} \mathrm{C}$. The NMR and IR spectra were similar to those of E-isomer.

2-Hydroxyiminomethyl-p-methoxyphenyl-pyridine 12 : This was prepared analogously to preparation 10, substituting 2-p-methoxybenzoyl-pyridine. However, no precipitate was obtained on cooling the chloroform solution. It was concentrated and the solid then obtained dissolved in $3 \mathrm{~N}$ aq. $\mathrm{HCl}$ Using copper sulfate as previoulsy described, a green precipitate was obtained, which was then converted to copper sulfide, the filtrate being treated with aq. $\mathrm{NH}_{3}$ until $\mathrm{pH} 6$ was reached. The Z-isomer was thus obtained in $85 \%$ yield; m.p. $169-170{ }^{\circ} \mathrm{C}$; NMR $\left(\mathrm{CDCl}_{3}\right): \delta=8.6-8.8(\mathrm{~d}, 1 \mathrm{H}), 6.7-8.4(\mathrm{~m}, 7 \mathrm{H}), 3.8(\mathrm{~s}, 3 \mathrm{H})$; IR (KBr pellet) : $v_{\max }\left(\mathrm{cm}^{-1}\right)=3300-2500$ (combined O-H, Ar-H, Py-H); 2900- 2800 $\left(\mathrm{C}-\mathrm{H}, \mathrm{OCH}_{3}\right), 1600(\mathrm{C}=\mathrm{N}), 1250$ (Ar-OR).

2-Hydroxyiminomethyl-p-nitrophenyl-pyridine 13 : This was prepared analogously to preparation 10. As in preparation 12 only the Z-isomer was obtained, though in only 8 $\%$ yield; m.p. $252-255^{\circ} \mathrm{C}$; NMR (DMSO-d 6 ): $\delta=12.1$ (s, $1 \mathrm{H}, \mathrm{OH}$ ), 8.5-8.8 (d, lH), 8.4-7.2 $(\mathrm{m}, 7 \mathrm{H})$; IR (KBr pellet) : $\nu_{\max }\left(\mathrm{cm}^{-1}\right)=3300-2500$ (combined O-H, Ar-H, Py-H), 1590 $(\mathrm{C}=\mathrm{N}), 1500,1340\left(\mathrm{C}-\mathrm{NO}_{2}\right)$. 
2-Hydroxyiminomethyl-p-fluorophenyl-pyridine 14 : This was prepared analogously to preparation 10, both $\mathrm{Z}$ - and E-isomers being obtained. The E-isomer was obtained in $24 \%$ yield; m.p. 167-169 ${ }^{\circ} \mathrm{C}$; NMR (DMSO-d 6 ) : $\delta=11.9$ (s, l H, O-H), 8.4-8.7 (d, 1 $\mathrm{H}$ ), 7.1-8.2 (m, 7H); IR (KBr pellet) : $\nu_{\max }\left(\mathrm{cm}^{-1}\right)=3450-2700$ (combined O-H, Ar-H, Py-H), $1600(\mathrm{C}=\mathrm{N}), 1220$ (C-F). The Z-isomer was obtained in only $6 \%$ yield; m.p. 194-197 ${ }^{\circ} \mathrm{C}$. The NMR and IR spectra were similar to those of E-isomer.

2-Hydroxyiminomethyl-p-chlorophenyl-pyridine 15 : This was prepared analogously to preparation 10, with some modification in the separation of E-and Z-isomers.

The crude product was dissolved in $3 \mathrm{~N}$ aq. $\mathrm{HCl}$ and copper (II) sulfate solution added. The green prepcipitate was resuspended in $3 \mathrm{~N}$ aq. $\mathrm{HCl}$ and saturated with $\mathrm{H}_{2} \mathrm{~S}$ (g). Copper sulfide was filtered off and aq. $\mathrm{NH}_{3}$ added until $\mathrm{pH} 6$ was obtained. The $\mathrm{Z}$-isomer was thus attained in $25 \%$ yield; m.p. $170-175^{\circ} \mathrm{C}$; NMR (DMSO-d 6 ) : $\delta=11.6$ (s, $1 \mathrm{H}, \mathrm{O}-\mathrm{H}), 8.4-8.6(\mathrm{~d}, 1 \mathrm{H}), 7.3(\mathrm{~s}, 4 \mathrm{H}), 7.0-8.3(\mathrm{~m}, 3 \mathrm{H})$; IR $(\mathrm{KBr}$ pellet $): v_{\max }\left(\mathrm{cm}^{-1}\right)$ =3450-2500 (combined O-H, Ar-H, Py-H), $1600(\mathrm{C}=\mathrm{N}), 1090$ (C-Cl).

The filtrate of the precipitation of the $\mathrm{Z}$-isomer was saturated with $\mathrm{H}_{2} \mathrm{~S}(\mathrm{~g})$. Copper sulfide was filtered off and aq. $\mathrm{NH}_{3}$ added until $\mathrm{pH} 6$ was obtained. The Eisomer was thus attained in only $8 \%$ yield; m.p. 201-202 ${ }^{\circ} \mathrm{C}$. The NMR and IR spectra were similar to those of $\mathrm{Z}$-isomer.

1-Methy 1-2-hydroxyminomethyl-phenyl-pyridinium iodide 16 (E-and Z-isomers) : 0.001 mole $(0.198 \mathrm{~g})$ of E- or Z-2-hydroxyiminomethyl-phenyl-pyridine was dissolved in $2.5 \mathrm{ml}$ of warm acetone. $0.5 \mathrm{ml}$ of methyl iodide was added, while stirring manually. The mixture was then cooled and allowed to stand in the dark for 3 days. The pyridinium salt precipitated on addition of dry ether. The E-isomer was obtained in $87 \%$ yield;m.p. 206-208 ${ }^{\circ} \mathrm{C}$; NMR (DMSO- $\mathrm{d}_{6}$ ) : $\delta=13.1$ (s, O-H), 9.2-9.4 (d, 1H), 8.6-9.1 (t, 1H), 8.0-8.5 (dd, 2H), 7.3-7.9 (m, 5H), $4.2(\mathrm{~s}, 3 \mathrm{H})$; IR (KBr pellet) : $\nu_{\max }\left(\mathrm{cm}^{-1}\right)=3400-2700$ (combined O-H, Ar-H, Py-H), $2980\left(\mathrm{C}-\mathrm{H}: \mathrm{Py}^{+}-\mathrm{CH}_{3}\right), 1600(\mathrm{C}=\mathrm{N})$. The Z-isomer was obtained in $74 \%$ yield; m.p. $183-188{ }^{\circ} \mathrm{C}$. The NMR and IR spectra were similar to those of E-isomer.

1-Methyl-2-hydroxyiminomethyl-p-tolyl-pyridinium iodide 17 (E-and Z-isomers): These were prepared analogously to preparation 16 . The E-isomer was obtained in $64 \%$ yield; m.p. $181-185{ }^{\circ} \mathrm{C}$; NMR (DMSO-d 6 ) : $\delta=13.0$ (s, OH), 9.1-9.4 (d, $1 \mathrm{H}$ ), 8.5-8.9 (t, 1H), 7.9-8.4 (t, 2H), 7.1-7.7 (dd, 4H), $4.1(\mathrm{~s}, 3 \mathrm{H}), 2.3(\mathrm{~s}, 3 \mathrm{H}) ; \operatorname{IR}\left(\mathrm{KBr}\right.$ pellet) : $v_{\max }\left(\mathrm{cm}^{-1}\right)$ =3500-2500 (combined O-H, Ar-H, Py-H), 2980 (C-H: Py $\left.{ }^{+}-\mathrm{CH}_{3}\right), 2850 \mathrm{C}-\mathrm{H}\left(\mathrm{Ar}-\mathrm{CH}_{3}\right)$, $1600(\mathrm{C}=\mathrm{N})$. The $\mathrm{Z}$ isomer was obtained in $27 \%$ yield; m.p. $110-120{ }^{\circ} \mathrm{C}$. The NMR and IR spectra were similar to those of E-isomer.

1-Methyl-2-hydroxyiminomethyl-p-anisyl-pyridinium iodide 18 (Z-isomer): This was prepared analogously to preparation 16 . The $Z$-isomer was obtained in $60 \%$ yield; m.p. 176-180 ${ }^{\circ} \mathrm{C}$; NMR (DMSO- $\mathrm{d}_{6}$ ) : $\delta=12.9$ (s, O-H); 9.0-9.3 (d, $1 \mathrm{H}$ ); 8.5-8.9 (t, $1 \mathrm{H}$ ); 8.0-8.5 (t, $2 \mathrm{H}) ; 7.5-7.8(\mathrm{~d}, 2 \mathrm{H}) ; 6.8-7.2(\mathrm{~d}, 2 \mathrm{H}) ; 4.2(\mathrm{~s}, 3 \mathrm{H}) ; 3.8$ (s, 3H); IR (KBr pellet): $v_{\max }\left(\mathrm{cm}^{-1}\right)=3500-2600$ (combined O-H, Ar-H, Py-H); $2980\left(\mathrm{C}-\mathrm{H}: \mathrm{Py}^{+}-\mathrm{CH}_{3}\right.$ ); $2840 \mathrm{C}-\mathrm{H}$ $\left(\mathrm{Ar}-\mathrm{OCH}_{3}\right) ; 1600(\mathrm{C}=\mathrm{N}) ; 1260$ (Ar-OR). 
1-Methyl-2-hydroxyiminomethyl-p-fluorophenyl-pyridinium iodide 19 (E- and Z-isomers): These were prepared analogously to preparation 16. The E-isomer was obtained in 24 \% yield; m.p. $180-182{ }^{\circ} \mathrm{C}$; NMR (DMSO-d 6 ) : $\delta=9.0-9.3$ (d, $1 \mathrm{H}$ ), 7.0-8.9 (m, 7H), 4.2 (s, 3H); IR (KBr pellet) : $v_{\max }\left(\mathrm{cm}^{-1}\right)=3500-2600$ (combined O-H, Ar-H, Py-H), 3000 $\left(\mathrm{C}-\mathrm{H}: \mathrm{Py}^{+}-\mathrm{CH}_{3}\right), 1600(\mathrm{C}=\mathrm{N}), 1230(\mathrm{C}-\mathrm{F})$. The $\mathrm{Z}$-isomer was obtained in quantitative yield; m.p. $114-120{ }^{\circ} \mathrm{C}$. The NMR and IR spectra were similar to those of E-isomer.

1-Methyl-2-hydroxyiminomethyl-p-chlorophenyl-pyridinium iodide 20 (E- and Z-isomers) : These were prepared analogously to preparation 16. The E-isomer was obtained in 62 \% yield; m.p. $212-218{ }^{\circ} \mathrm{C}$; NMR (DMSO-d 6 ) : $\delta=13.2$ (s, O-H), 9.1-9.3 (d, 1H), 8.5-8.9 $(\mathrm{t}, \mathrm{lH}), 8.0-8.4(\mathrm{dd}, 2 \mathrm{H}), 7.4-7.8(\mathrm{dd}, 4 \mathrm{H}), 4.2(\mathrm{~s}, 3 \mathrm{H}) ;$ IR (KBr pellet): $v_{\max }$ $\left(\mathrm{cm}^{-1}\right)=3300-2800$ (combined O-H, Ar-H, Py-H), $3000\left(\mathrm{C}-\mathrm{H}: \mathrm{Py}^{+}-\mathrm{CH}_{3}\right), 1620(\mathrm{C}=\mathrm{N})$; 1170 (C-Cl). The Z-isomer was obtained in $48 \%$ yield; m.p. $196-198{ }^{\circ} \mathrm{C}$. The NMR and IR spectra were similar to those of E-isomer.

1-Methyl-2-hydroxyiminomethyl-p-nitrophenyl-pyridinium iodide 21 (Z-isomer) : This prepared analogously to preparation 16 . The $Z$-isomer was obtained in $42 \%$ yield; m.p. $219-220{ }^{\circ} \mathrm{C}$.

\section{Acknowledgements}

The authors thank the Coordenadoria de Aperfeigoamento de Pessoal de Ensino Superior (CAPES) for a scholarship (I. C.) CAPES/PICD.

\section{References}

(1) R.I. Ellin, Gen. Pharmacol. 13, 457 (1982)

(2) C.J. Briggs and K.J. Simons, Pharm. Int. 7, 155 (1986)

(3) N. Bodor, E. Shek and T. Higuchi, J. Med. Chem. 19, 102 (1976)

(4) A.M. Singer, S.H. McElvain, Org. Synth. Coll. 3, 740 (1957)

(5) N. Sperber, D. Papa, E. Schwenk and M. Sherlock, J. Amer. Chem. Soc. 71,887 (1949)

(6) A. Bowers, T. G. Halsall, E.R.H. Jones and A.J. Lemin, J. Chem. Soc. 2548 (1953)

(7) H.E. Baumgarten, Org. Synth. Coll. 5, 310, 866 (1973)

(8) F.J. Villani, M.S. King and D. Papa, J. Org. Chem. 17, 249 (1952)

(9) E.H. Huntress and H.C. Walter, J. Amer. Chem. Soc. $\underline{70}, 3702$ (1948)

(10) F.H. Case and P.J. MeMenamin, J. Heterocycl. Chem. 5, 161 (1968)

(11) R.J. Kitz, S. Ginsburg and I.B. Wilson, Biochem. Pharmacol. 14, 1471 (1965)

(12) C.F. Barfknecht, J.D. Long and F.W. Benz, J. Pharm. Sci. 므, 138 (1971)

(13) C.J. Pouchert (Ed). The Aldrich Library of Infrared Spectra, Aldrich Chemical Company, Wisconsin, USA, 1975

(14) C.J. Pouchert (Ed.), The Aldrich Library of NMR Spectra, Aldrich Chemical Company, wisconsin, USA, 1983

Received March 15, 1995 